\title{
Effect of Citrus Fiber Addition on Quality Attributes of Fully Cooked Deli-Style Turkey Breast ${ }^{1}$
}

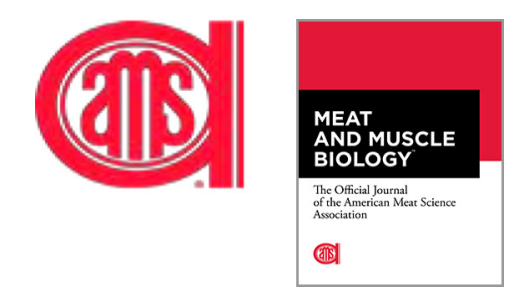

\author{
McKenna J. Powell ${ }^{1}$, Joseph G. Sebranek ${ }^{1,2}$, Kenneth J. Prusa ${ }^{1,2}$, and Rodrigo Tarté ${ }^{1,2 *}$ \\ ${ }^{1}$ Department of Animal Science, lowa State University, Ames, IA 50011, USA \\ ${ }^{2}$ Department of Food Science and Human Nutrition, lowa State University, Ames, IA 50011, USA \\ *Corresponding author. Email: rtarte@iastate.edu (Rodrigo Tarté) \\ ${ }^{1}$ This paper is a product of the lowa Agriculture and Home Economics Experiment Station, Ames, Iowa, USA, \\ Project No. IOW03721, which is sponsored by Hatch Act and State of lowa funds.
}

\begin{abstract}
The effects of citrus fiber on the color, texture, lipid oxidation, and sensory characteristics of fully cooked deli-style turkey breast during storage $\left(3^{\circ} \mathrm{C}\right)$ were studied. Four treatments were evaluated: control, $0.25 \%$ citrus fiber, $0.50 \%$ citrus fiber, and $0.105 \%$ sodium tripolyphosphate. The study was independently replicated 3 times. Proximate analysis and $\mathrm{pH}$ were measured once, and color (Hunter L, a, b), lipid oxidation (thiobarbituric acid-reactive substances), texture (Texture Profile Analysis hardness, resilience, cohesiveness, springiness, and chewiness), and sensory parameters (turkey aroma, texture, moistness, turkey flavor, off-flavor, and color) were measured at regular intervals on vacuum-packaged samples throughout an 84-d storage period. Aside from Texture Profile Analysis resiliency and sensory moistness lower in the $0.105 \%$ sodium tripolyphosphate group, all experimental treatments resulted in product with equivalent quality attributes to the control. At the levels tested in this specific application (high moisture, low fat), the citrus fiber evaluated did not affect the product's quality attributes in a measurable way.
\end{abstract}

Key words: citrus fiber, clean label, sodium phosphate, turkey breast

Meat and Muscle Biology 5(1): 35, 1-8 (2021)

doi: $10.22175 / \mathrm{mmb} .12283$

Submitted 26 February $2021 \quad$ Accepted 17 June 2021

\section{Introduction}

In the last decade, growing skepticism from some consumers regarding food additives has created a demand and market for so-called "clean label" products. The term "clean label," though it does not have a widely agreed-upon definition, is generally given to products devoid of ingredients that must be declared on their labels by their common chemical names (Baines and Seal, 2012). Although all food additives used in processing provide specific functionality, many of them are perceived as unnatural, unhealthy, or unsafe. This has prompted the food industry to search for natural alternatives to conventional ingredients that possess the similar functional properties, and the meat industry has not been exempt from this challenge. Some of the most scrutinized ingredients commonly found in processed meat products include sodium nitrite/nitrate, sodium erythorbate/ascorbate, and phosphates. This has led to the use of celery juice powder and cherry powder as natural alternatives to sodium nitrite/nitrate and sodium erythorbate/ascorbate, respectively (Sebranek and Bacus, 2007), but there has been little published research on natural alternatives to phosphate in processed meats.

Phosphates increase myofibrillar swelling and improve water-holding capacity by increasing $\mathrm{pH}$ and ionic strength and facilitating protein extraction (Xiong, 2000) and, in this way, contribute to water retention, texture, and sensory properties. For this reason, their complete removal from meat and poultry products is not always possible; therefore, the use of various binders and starches as functional alternatives to phosphate have been researched (Sen et al., 2005; Lee et al., 2015). Among these are ingredients such as bicarbonates (Sen et al., 2005; Lee et al., 2015), porcine 
blood plasma (Hurtado et al., 2012), wheat bran, modified tapioca starch and sodium citrate (Ruusunen et al., 2003), and, more recently, winter mushroom powder (Choe etal., 2018), potassium bicarbonate (LeMaster et al., 2019), and chia mucilage (Câmara et al., 2020). However, there remain challenges associated with using alternative sources to replace phosphate, namely maintenance of water-holding capacity, texture and mouthfeel, buffering ability, and sensory properties.

Different fibers and high-fiber ingredients have the potential to be used as alternatives to phosphates or other binder ingredients because of their high surface area, which can contribute to improved water retention, processing yields, and texture. Defined as "the remnants of plant cells resistant to digestion by human enzymes... whose components are hemicellulose, cellulose, pectin, lignin, oligosaccharides, gums, and waxes" (Trowell et al., 1985), various types of dietary fibers have been studied (individually or in combination with other additives) in various meat products, such as pork sausages (Desmond and Troy, 2003), pork emulsions (Kim et al., 2015), frankfurter-type sausage (Chang and Carpenter, 1997; Steenblock et al., 2001), ground pork (Choi et al., 2010), Bologna sausage (Claus and Hunt, 1991; Steenblock et al., 2001; Pietrasik and Janz, 2010), beef patties (Mansour and Khalil, 1999; Anderson and Berry, 2000), and fermented sausages (García et al., 2002). One particular fiber ingredientcitrus fiber-has also been investigated in processed meat products (Fernández-Ginés et al., 2003; Fernández-López et al., 2004; Tomaschunas et al., 2013; Song et al., 2016), but it has only recently been considered as a potential replacement for ingredients such as phosphates (Powell et al., 2019). It is sourced from the pulp or juice vesicles of oranges (Citrus sinensis) and has been reported to possess high internal surface area, apparent viscosity, and water-holding capacity, which in principle makes it similar to phosphates (Lundberg, 2005), owing primarily to its high pectin and hemicellulose content (Lundberg et al., 2014).

The objective of this study was to evaluate the effects of citrus fiber addition on the physical, chemical, and sensory properties of fully cooked deli turkey over a storage period of $84 \mathrm{~d}$.

\section{Materials and Methods}

\section{Use of human subjects}

The sensory analysis protocol used in this study was reviewed and approved by the Iowa State University
Institutional Review Board (16 November 2016; IRB ID 16-527), and informed consent was obtained from all panel participants prior to initiation of the study.

\section{Formulation materials}

Frozen turkey breasts (pectoralis major) were sourced from a commercial turkey plant, sodium nitrite and sodium erythorbate from A.C. Legg, Inc. (Calera, AL), dried vinegar powder (Verdad N6) from Corbion (Lenexa, KS), sodium tripolyphosphate from Innophos (Cranbury, NJ), and citrus fiber (Citri-Fi 100M40) from FiberStar, Inc. (River Falls, WI).

\section{Product manufacture}

Approximately 1 week before manufacture, frozen turkey breasts were delivered to the Iowa State University Meats Laboratory and stored frozen at $-40^{\circ} \mathrm{C}$. As needed, meat was thawed at $4.4^{\circ} \mathrm{C}$ for $2 \mathrm{~d}$ and then moved into a cooler at $0^{\circ} \mathrm{C}-1{ }^{\circ} \mathrm{C}$ for $1 \mathrm{~d}$. On the day of production, injection brines were prepared according to the formulations shown in Table 1 by adding ingredients in the following order: sodium tripolyphosphate (when present), sodium erythorbate, citrus fiber (when present), salt, dextrose, dried vinegar, and sodium nitrite. The order of manufacture of treatments was randomized prior to production. Approximately $11.5 \mathrm{~kg}$ of whole turkey breast halves were injected with brine to a target of $20 \%$ over the meat weight using an automated multi-needle injector (model PIH 21; Günther Maschinenbau GmbH, Dieburg, Germany) and tumbled under vacuum (model DFE 50 vacuum tumbler; Daniels Food Equipment Inc., Parkers Prairie, MN) for $2 \mathrm{~h}$ at approximately $16 \mathrm{rpm}$. The turkey breasts were then loaded into a vacuum stuffer (Handtmann model VF 608 plus; Albert Handtmann Maschinenfabrik GmbH \& Co. $\mathrm{KG}$, Riss, Germany) and stuffed into clear, pre-stuck

Table 1. Injection brine formulations of oven-roasted turkey breast (percentage basis)

\begin{tabular}{lrrrr}
\hline \hline & CON & $0.25 \mathrm{CF}$ & $0.50 \mathrm{CF}$ & PHO \\
\hline Water & 85.45 & 83.95 & 82.45 & 84.83 \\
Salt & 8.40 & 8.40 & 8.40 & 8.40 \\
Dextrose & 3.75 & 3.75 & 3.75 & 3.75 \\
Dried Vinegar & 2.10 & 2.10 & 2.10 & 2.10 \\
Sodium Tripolyphosphate & 0.00 & 0.00 & 0.00 & 0.63 \\
Citrus Fiber & 0.00 & 1.50 & 3.00 & 0.00 \\
Sodium Erythorbate & 0.25 & 0.25 & 0.25 & 0.25 \\
Sodium Nitrite & 0.05 & 0.05 & 0.05 & 0.05 \\
\hline
\end{tabular}

$\mathrm{CON}=$ control; $0.25 \mathrm{CF}=0.25 \%$ citrus fiber; $0.50 \mathrm{CF}=0.50 \%$ citrus fiber; $\mathrm{PHO}=$ sodium tripolyphosphate. 
Table 2. Thermal processing schedule of cooked delistyle turkey breast

\begin{tabular}{lcccccc}
\hline \hline & $\begin{array}{c}\text { Step } \\
\text { Time } \\
(\mathrm{min})\end{array}$ & $\begin{array}{c}\text { Dry } \\
\text { Bulb } \\
\left({ }^{\circ} \mathrm{C}\right)\end{array}$ & $\begin{array}{c}\text { Wet } \\
\text { Bulb } \\
\left({ }^{\circ} \mathrm{C}\right)\end{array}$ & $\begin{array}{c}\text { Relative } \\
\text { Humidity } \\
(\%)\end{array}$ & $\begin{array}{c}\text { Main } \\
\text { Blower }\end{array}$ & $\begin{array}{c}\text { Exhaust } \\
\text { Damper }\end{array}$ \\
\hline $\begin{array}{l}\text { Steam } \\
\text { Cook }\end{array}$ & $1: 00$ & 60 & 60 & 100 & 5 & Closed \\
$\begin{array}{l}\text { Steam } \\
\text { Cook }\end{array}$ & $0: 30$ & 66 & 66 & 100 & 5 & Closed \\
$\begin{array}{l}\text { Steam } \\
\text { Cook }\end{array}$ & $0: 30$ & 71 & 71 & 100 & 5 & Closed \\
$\begin{array}{l}\text { Steam } \\
\text { Cook }\end{array}$ & $0: 05$ & 82 & 82 & 100 & 5 & Closed \\
Cold & $0: 20$ & 10 & 0 & 0 & 0 & Auto \\
Shower & & & & & & \\
\hline
\end{tabular}

$32.4 \mathrm{~cm}$ (circumference) $\times 101.6 \mathrm{~cm}$ (length) fibrous casings (Kalle USA Inc., Gurnee, IL). Turkey logs were weighed, placed on a smoke truck in a random arrangement, moved into an Alkar oven (DEC International, Inc., Lodi, WI), and thermally processed following the schedule shown in Table 2. After overnight cooling (approximately $18 \mathrm{~h}$ ) at $0^{\circ} \mathrm{C}-1^{\circ} \mathrm{C}, \operatorname{logs}$ were reweighed, casings were removed, and logs were sliced manually (slicer model SE $12 \mathrm{D}$; Bizerba $\mathrm{GmbH} \&$ Co. KG, Balingen, Germany) into 1-mm-thick slices weighing $14 \mathrm{~g}$ each. Four slices per bag were placed in high-barrier bags (oxygen transmission rate: $3-6 \mathrm{~cm}^{3} / \mathrm{m}^{2} / 24 \mathrm{~h}$ at $23^{\circ} \mathrm{C}, 0 \%$ relative humidity; water vapor transmission rate: $7.8-9.3 \mathrm{~g} / \mathrm{m}^{2} / 24 \mathrm{~h}$ at $38^{\circ} \mathrm{C}, 100 \%$ relative humidity; Cryovac Sealed Air Corporation, Duncan, SC) and vacuum sealed (Ultravac UV 2100 packaging machine; Koch Equipment, Kansas City, MO). All treatments were subsequently stored at $3^{\circ} \mathrm{C}$ for the remainder of the study, either under 3,500-K fluorescent lights (Sylvania, Danvers, MA) to simulate retail display or inside cardboard boxes with no light exposure. The distance between sample surface and light source was approximately $22 \mathrm{~cm}$. The day of packaging was designated as day 0 .

\section{Proximate analysis}

Fat, moisture, and protein contents were measured in duplicate for each treatment. Fat content and moisture content were measured following Official Methods 960.39 and 950.46 of AOAC International (2016), respectively. Samples were dried in a VWR 1370GM oven (Sheldon Manufacturing Inc., Cornelius, OR). and extracted with hexane in a Soxhlet multi-unit extraction-heating unit (Lab-Line Instruments, Inc., Melrose Park, IL). Protein content was measured following Official Method 992.15 of AOAC International (2016) using a TruMac $\mathrm{N}$ combustion nitrogen/protein analyzer (Leco Corporation, St. Joseph, MI).

\section{pH}

Ten grams of sample was ground and mixed with $90 \mathrm{~mL}$ of distilled water in a $150-\mathrm{mL}$ beaker and stirred vigorously for $60 \mathrm{~s}$. The mixture was filtered $(11-\mu \mathrm{m}$ filter paper, Whatman Grade 1, GE Healthcare Life Sciences, Pittsburgh, PA), and the $\mathrm{pH}$ of the filtrate was read using a SevenMulti $\mathrm{pH}$ meter equipped with an InLab Solids Pro-ISM electrode (Mettler Toledo, Columbus, $\mathrm{OH}) . \mathrm{pH}$ readings were done in duplicate and averaged.

\section{2-Thiobarbituric acid analysis}

The oxidative rancidity of samples stored under retail display conditions was measured on days $0,14,28,56$, and 84 by the 2-thiobarbituric acid procedure of Tarladgis et al. (1960), as modified by Zipser and Watts (1962) for cured products. Absorbance at $532 \mathrm{~nm}$ was measured using a spectrophotometer (Beckman DU640 model 4320940; Beckman Instruments, Inc., Fullerton, CA). Analyses were performed in duplicate, and results were averaged.

\section{Instrumental color analysis}

Color was measured on days $0,14,28,56$, and 84 using a HunterLab LabScan XE colorimeter (model LS 1500; Hunter Associated Laboratories, Inc., Reston, VA) using illuminant D65 (daylight at $6,500 \mathrm{~K}$ ), $10^{\circ}$ observer angle, and 2.54- $\mathrm{cm}$ aperture. The Hunter L, a, b color space was used. Saran-brand clear plastic film (S.C. Johnson \& Son, Inc., Racine, WI) was placed over the calibration tiles to account for the packaging material of retail display samples. Measurements were taken on the surface of all samples at 3 different locations for a total of 3 random surface measurements per sample.

\section{Texture Profile Analysis}

Texture Profile Analysis (TPA) was done in triplicate on days $0,14,28,56$, and 84 using a TA-XT2i Texture Analyzer (Stable Micro Systems, Surrey, UK). Unsliced turkey samples were cut to a thickness of $2.54 \mathrm{~cm}$, cored to a diameter of $2.54 \mathrm{~cm}$, and subjected to a simplified TPA test. All instrumental texture analyses were conducted on chilled samples $\left(0^{\circ} \mathrm{C}-1^{\circ} \mathrm{C}\right)$. The samples were compressed twice to $35 \%$ of their original height at a test speed of $5.00 \mathrm{~mm} \mathrm{~s}^{-1}$ and a trigger force of $0.049 \mathrm{~N}$. The texture profile parameters hardness, 
resilience, cohesiveness, springiness, and chewiness were determined as described by Bourne (1978).

\section{Sensory analysis}

Sensory analysis was conducted on days $14,28,56$, and 84 using a 10-member trained sensory panel. Panel participants were students, faculty, and staff of Iowa State University's Departments of Food Science and Human Nutrition and of Animal Science. Two separate training sessions were held on different days during the week before the first test session, utilizing samples from this study. By the end of the second session, general agreement was achieved among panel members regarding the definition and magnitude of the sensory attributes evaluated. Every test session, a 3-digit code was randomly assigned to each treatment sample. Prior to serving, sample slices were cut into 8 wedges, and the pieces were placed in a large bowl and mixed to ensure randomization. Four wedges were placed in a cup with a lid and held under refrigeration for approximately $30 \mathrm{~min}$ prior to evaluation. Each panelist tested the samples inside a cubicle illuminated with red lights. Water and plain crackers were provided as palette cleanser. For color evaluation, an intact slice of each test sample was placed on white butcher paper and evaluated by the panelists under sunlight next to an exterior-facing window. Panelists recorded their evaluation on a $15-\mathrm{cm}$ line scale, and data were collected using Compusense five (release 5.6) sensory evaluation software (Compusense, Inc., Guelph, ON, Canada). Sensory attributes evaluated were turkey aroma ("none" to "intense"), texture ("soft" to "firm"), moistness ("not moist" to "moist"), turkey flavor ("none" to "intense"), off-flavor ("none" to "intense"), and color ("light" to "dark"). During sample manufacturing, product from replication 1 was accidentally rendered inedible; therefore, sensory analysis was performed on samples from replications 2 and 3 only.

\section{Experimental design and statistical analysis}

The experiment was designed as a randomized complete block design. For each replication, assignment of experimental treatments to manufacturing batches and placement of stuffed logs for thermal processing were done randomly. The experiment was replicated independently 3 times (twice for sensory analysis), with replications as blocks, and each replication corresponded to a different consecutive manufacturing day. To reduce experimental error by minimizing within-block variation, all raw materials used were from the same production lot.

Data were analyzed as a mixed model using the PROC MIXED procedure of SAS (version 9.4; SAS
Institute, Cary, NC), with the fixed factors of treatment, storage time, and treatment $\times$ storage time interaction and the random factors of replication, replication $\times$ storage time, sensory test sessions, and panelists. Differences between treatments and within treatments over time were determined using the Tukey-Kramer pairwise comparison method. Significance was established at $P<0.05$.

\section{Results and Discussion}

\section{Proximate analysis, $\mathrm{pH}$, and cook/chill yields}

The proximate composition, $\mathrm{pH}$ and cook/chill yields of the cooked deli-style turkey samples are shown in Table 3. There were no treatment effects $(P>0.05)$ for fat, moisture and protein content, and cook/chill yield. The $\mathrm{pH}$ of $0.50 \%$ citrus fiber $(0.50 \mathrm{CF})$ was lower $(P<0.05)$ than for all other treatments, likely because of the acidic nature of the citrus fiber.

\section{Instrumental color}

Color results - expressed as Hunter L, a, b values -are shown in Tables 4 and 5. For samples stored in the dark, no significant treatment, storage time, or treatment $\times$ storage time effects were observed for $\mathrm{L}$ or a values. There were significant treatment, storage time, and treatment $\times$ storage time effects for $b$ values, which were higher (yellower) in citrus fiber treatments than the control $(\mathrm{CON})$ and $0.105 \%$ sodium tripolyphosphate (PHO) groups. However, the only day when the effect was significant was day 0 . For samples stored under retail display lights, $\mathrm{L}$ values were not different $(P>0.05)$ over storage time or treatment $\times$ storage time, but a treatment effect $(P<0.05)$ was observed,

Table 3. Proximate composition, $\mathrm{pH}$, and cook/chill yield of cooked deli-style turkey ${ }^{1}$

\begin{tabular}{lccccc}
\hline \hline Treatment & Moisture \% & Protein \% & Fat \% & $\mathrm{pH}$ & Yield \% \\
\hline Control & $72.03^{\mathrm{a}}$ & $25.03^{\mathrm{a}}$ & $1.67^{\mathrm{a}}$ & $6.19^{\mathrm{a}}$ & $79.14^{\mathrm{a}}$ \\
$\mathbf{0 . 2 5 C F}$ & $72.53^{\mathrm{a}}$ & $24.37^{\mathrm{a}}$ & $1.49^{\mathrm{a}}$ & $6.18^{\mathrm{a}}$ & $81.30^{\mathrm{a}}$ \\
$\mathbf{0 . 5 0 C F}$ & $71.59^{\mathrm{a}}$ & $25.07^{\mathrm{a}}$ & $1.54^{\mathrm{a}}$ & $6.09^{\mathrm{b}}$ & $77.14^{\mathrm{a}}$ \\
PHO & $72.66^{\mathrm{a}}$ & $24.12^{\mathrm{a}}$ & $1.52^{\mathrm{a}}$ & $6.18^{\mathrm{a}}$ & $80.91^{\mathrm{a}}$ \\
SEM & 0.37 & 0.46 & 0.14 & 0.02 & 0.75 \\
\hline
\end{tabular}

${ }^{1}$ Means of 3 replications. All analyses performed in duplicate.

${ }^{a, b}$ Means in the same column with different letters are significantly different $(P<0.05)$.

$0.25 \mathrm{CF}=0.25 \%$ citrus fiber; $0.50 \mathrm{CF}=0.50 \%$ citrus fiber; $\mathrm{PHO}=$ sodium tripolyphosphate; $\mathrm{SEM}=$ standard error of the mean. 
Table 4. Means for effect of treatment on Hunter L, a, b values of cooked deli-style turkey stored in the dark or under retail display lights ${ }^{1}$

\begin{tabular}{lccccccc}
\hline \hline & \multicolumn{3}{c}{ Dark } & & \multicolumn{3}{c}{ Retail Display } \\
\cline { 2 - 4 } \cline { 6 - 7 } Treatment & $\mathrm{L}$ & $\mathrm{a}$ & $\mathrm{b}$ & & $\mathrm{L}$ & $\mathrm{a}$ & $\mathrm{b}$ \\
\hline CON & $70.31^{\mathrm{a}}$ & $7.53^{\mathrm{a}}$ & $8.80^{\mathrm{b}}$ & & $71.31^{\mathrm{ab}}$ & $7.10^{\mathrm{a}}$ & $9.32^{\mathrm{b}}$ \\
$\mathbf{0 . 2 5 C F}$ & $70.94^{\mathrm{a}}$ & $7.19^{\mathrm{a}}$ & $9.14^{\mathrm{a}}$ & & $71.77^{\mathrm{ab}}$ & $6.93^{\mathrm{ab}}$ & $9.61^{\mathrm{a}}$ \\
$\mathbf{0 . 5 0 C F}$ & $70.21^{\mathrm{a}}$ & $7.46^{\mathrm{a}}$ & $9.40^{\mathrm{a}}$ & & $72.65^{\mathrm{a}}$ & $6.49^{\mathrm{b}}$ & $9.69^{\mathrm{a}}$ \\
PHO & $70.23^{\mathrm{a}}$ & $7.44^{\mathrm{a}}$ & $8.59^{\mathrm{b}}$ & & $71.02^{\mathrm{b}}$ & $6.90^{\mathrm{ab}}$ & $9.23^{\mathrm{b}}$ \\
SEM & 0.38 & 0.14 & 0.07 & & 0.40 & 0.13 & 0.06 \\
\hline
\end{tabular}

${ }^{1}$ Means of 3 replications. All analyses performed in duplicate.

${ }^{a, b}$ Means in the same column with different letters are significantly different $(P<0.05)$.

$\mathrm{CON}=$ control; $0.25 \mathrm{CF}=0.25 \%$ citrus fiber; $0.50 \mathrm{CF}=0.50 \%$ citrus fiber; $\mathrm{PHO}=$ sodium tripolyphosphate; $\mathrm{SEM}=$ standard error of the mean.

Table 5. Means for effect of storage time on instrumental (Hunter Lab) color values of cooked deli-style turkey stored in the dark or under retail display lights ${ }^{1}$

\begin{tabular}{lccccccc}
\hline \hline & \multicolumn{3}{c}{ Dark } & & \multicolumn{3}{c}{ Retail Display } \\
\cline { 2 - 4 } \cline { 6 - 8 } & $\mathrm{L}$ & $\mathrm{a}$ & $\mathrm{b}$ & & $\mathrm{L}$ & $\mathrm{a}$ & $\mathrm{b}$ \\
\hline 0 & $70.06^{\mathrm{a}}$ & $7.48^{\mathrm{a}}$ & $9.34 \mathrm{a}$ & & $72.07^{\mathrm{a}}$ & $5.80^{\mathrm{c}}$ & $10.98^{\mathrm{a}}$ \\
14 & $70.49^{\mathrm{a}}$ & $7.42^{\mathrm{a}}$ & $8.89^{\mathrm{b}}$ & & $70.82^{\mathrm{a}}$ & $7.46^{\mathrm{a}}$ & $9.31^{\mathrm{b}}$ \\
28 & $70.61^{\mathrm{a}}$ & $7.43^{\mathrm{a}}$ & $8.90^{\mathrm{b}}$ & & $71.06^{\mathrm{a}}$ & $7.23^{\mathrm{ab}}$ & $9.12^{\mathrm{bc}}$ \\
56 & $70.52^{\mathrm{a}}$ & $7.34^{\mathrm{a}}$ & $8.92^{\mathrm{b}}$ & & $72.32^{\mathrm{a}}$ & $6.92^{\mathrm{ab}}$ & $8.89^{\mathrm{c}}$ \\
84 & $70.45^{\mathrm{a}}$ & $7.37^{\mathrm{a}}$ & $8.86^{\mathrm{b}}$ & & $72.14^{\mathrm{a}}$ & $6.86^{\mathrm{b}}$ & $9.01^{\mathrm{c}}$ \\
SEM & 0.43 & 0.15 & 0.08 & & 0.44 & 0.14 & 0.07 \\
\hline
\end{tabular}

${ }^{1}$ Means of 3 replications. All analyses performed in duplicate.

${ }^{\mathrm{a}-\mathrm{c}}$ Means in the same column with different letters are significantly different $(P<0.05)$.

$\mathrm{SEM}=$ standard error of the mean.

with $0.50 \mathrm{CF}$ being lighter than PHO. For Hunter a and $b$ values, significant effects were observed for treatment, storage time, and treatment $\times$ storage time, with CON being significantly redder than $0.50 \mathrm{CF}$ (except not at day 0 ) and citrus fiber treatments being yellower than CON and PHO, likely owing to the yellowish hue of the citrus fiber ingredient.

For all samples, Hunter $b$ values decreased significantly between day 0 and day 14 , but not thereafter. These results agree with Beggs et al. (1997), who reported that inclusion of pea fiber affected only $b^{*}$ values and not $L^{*}$ or $a^{*}$ values in turkey frankfurters. Similarly, a study on turkey bologna found that the inclusion of soy protein isolate increased product yellowness (Omana et al., 2012). In this study, although some differences in instrumental color values were significant $(P<0.05)$, they were too small to be perceived by the sensory panel.

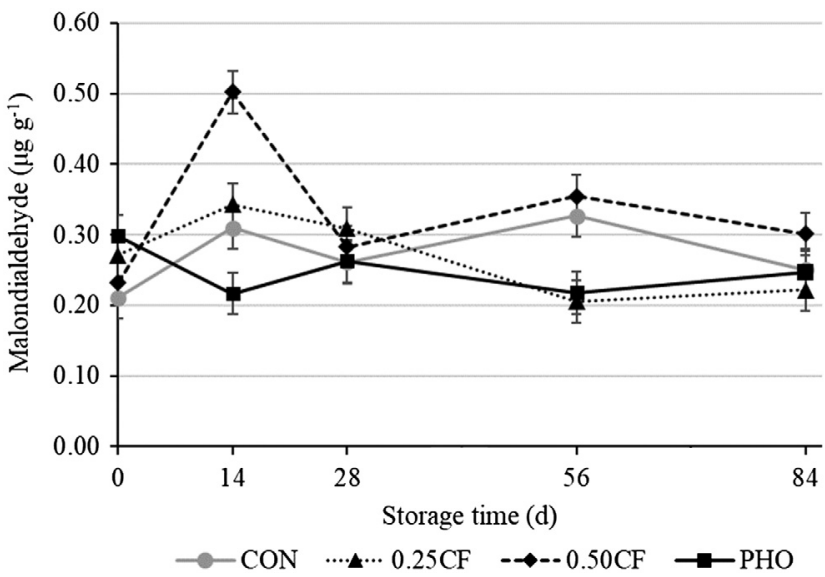

Figure 1. TBARS values of deli-style turkey breast during storage under retail display lights at $3^{\circ} \mathrm{C}$. Error bars represent $\pm \mathrm{SEM}(=0.06)$. Means of 3 replications. All analyses performed in duplicate. SEM $=$ standard error of the mean; TBARS, thiobarbituric acid-reactive substances; $\mathrm{CON}=$ control; $0.25 \mathrm{CF}=0.25 \%$ citrus fiber; $0.50 \mathrm{CF}=0.50 \%$ citrus fiber; $\mathrm{PHO}=$ sodium tripolyphosphate

\section{Lipid oxidation}

Lipid oxidation results are shown in Figure 1. Thiobarbituric acid-reactive substances values were not different $(P>0.05)$ between $\mathrm{CON}, 0.25 \%$ citrus fiber $(0.25 \mathrm{CF}), 0.50 \mathrm{CF}$, and $\mathrm{PHO}$ throughout the 84 $\mathrm{d}$ storage period and never exceeded $0.51 \mathrm{mg}$ malondialdehyde $/ \mathrm{kg}$, indicating low levels of lipid oxidation, an observation confirmed by the sensory panel also (Figure 2E). Citrus fiber, therefore, had no effect on the lipid oxidative stability of this product.

\section{Texture Profile Analysis}

TPA results are shown in Table 6 . There were no treatment or storage time effects $(P>0.05)$ for any of the TPA parameters evaluated (hardness, resilience, cohesiveness, springiness, chewiness). The only pairwise significant difference observed was higher resilience in PHO than in $0.50 \mathrm{CF}$, suggesting that phosphate was more efficient at allowing the sample to regain its original shape after being compressed. Overall, these results indicate that citrus fiber generally did not affect textural properties, suggesting that, at the levels used, it was not able to improve the textural attributes of a binder- and phosphate-free turkey breast product. The higher resilience and directionally higher hardness and chewiness values of PHO suggest that higher phosphate concentrations could result in improved texture.

\section{Sensory analysis}

Sensory results are shown in Figure 2. There were no overall treatment or storage time effects $(P>0.05)$ for 

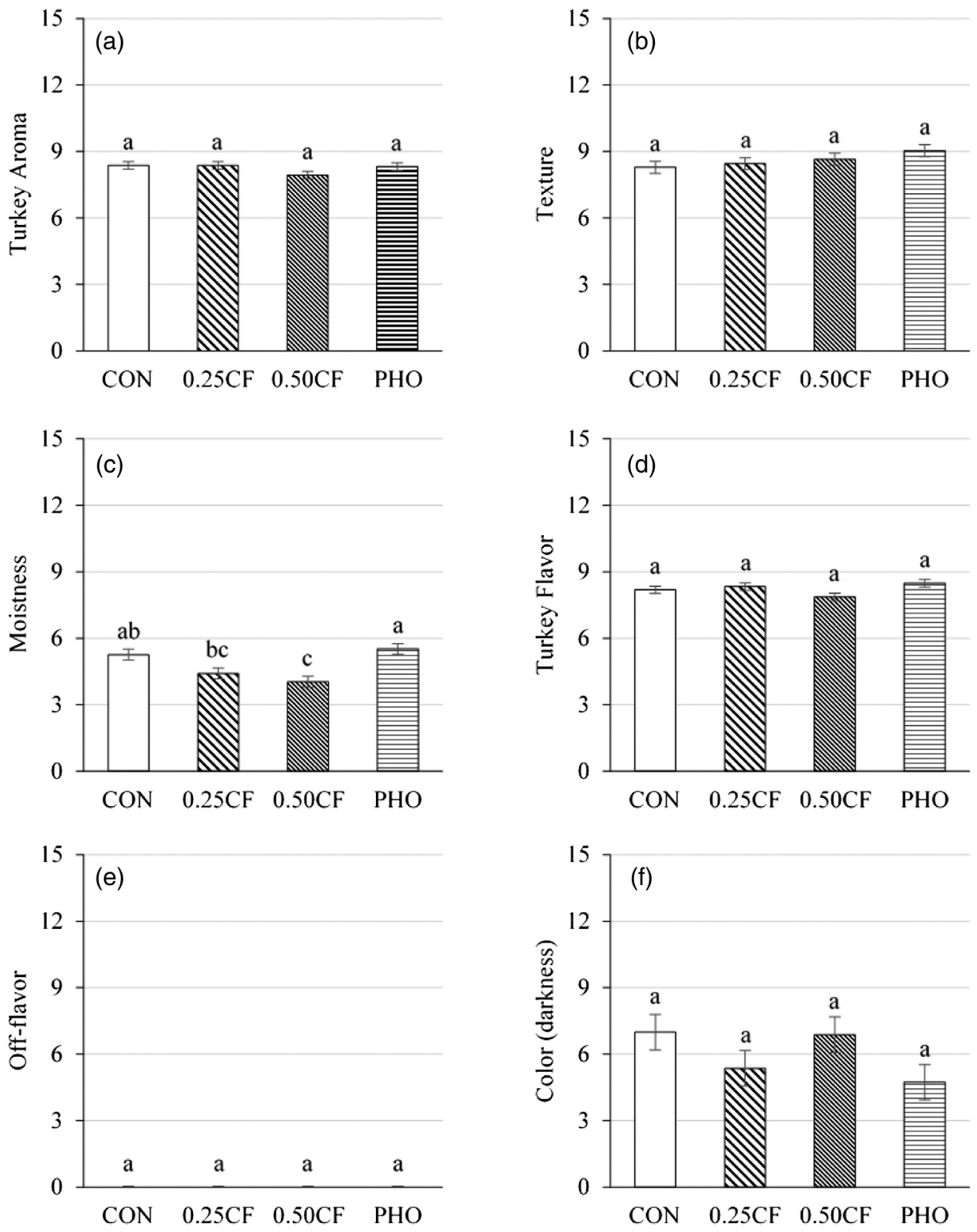

Figure 2. Sensory evaluation scores of deli-style turkey breast. Treatments with different letters differ significantly $(P<0.05)$. Error bars represent \pm SEM. Turkey aroma SEM $=0.17$. Texture $\mathrm{SEM}=0.27$. Moistness $\mathrm{SEM}=0.25$. Turkey flavor $\mathrm{SEM}=0.17$. Off-flavor $\mathrm{SEM}=0.04$. Lightness $\mathrm{SEM}=0.80$. Sensory evaluation was conducted on replications 2 and 3 only. $\mathrm{CON}=$ control; $0.25 \mathrm{CF}=0.25 \%$ citrus fiber; $0.50 \mathrm{CF}=0.50 \%$ citrus fiber; $\mathrm{PHO}=$ sodium tripolyphosphate $\mathrm{SEM}=$ standard error of the mean.

Table 6. Means for effect of treatment on instrumental texture of cooked deli-style turkey ${ }^{1}$

\begin{tabular}{lccccc}
\hline \hline Treatment & Hardness (N) & Resilience (\%) & Cohesiveness & Springiness (\%) & Chewiness (N mm) \\
\hline Control & $54.58^{\mathrm{a}}$ & $28.76^{\mathrm{ab}}$ & $0.62^{\mathrm{a}}$ & $77.78^{\mathrm{a}}$ & $26.69^{\mathrm{a}}$ \\
$\mathbf{0 . 2 5 C F}$ & $50.71^{\mathrm{a}}$ & $27.13^{\mathrm{ab}}$ & $0.59^{\mathrm{a}}$ & $74.86^{\mathrm{a}}$ & $23.18^{\mathrm{a}}$ \\
0.50CF & $56.02^{\mathrm{a}}$ & $26.29^{\mathrm{b}}$ & $0.59^{\mathrm{a}}$ & $75.89^{\mathrm{a}}$ & $25.59^{\mathrm{a}}$ \\
PHO & $57.57^{\mathrm{a}}$ & $29.69^{\mathrm{a}}$ & $0.62^{\mathrm{a}}$ & $77.07^{\mathrm{a}}$ & $28.35^{\mathrm{a}}$ \\
SEM & 2.94 & 0.72 & 0.01 & 1.36 & 1.91 \\
\hline
\end{tabular}

${ }^{1}$ Means of 3 replications. All analyses performed in duplicate.

${ }^{\mathrm{a}, \mathrm{b}}$ Means in the same column with different letters are significantly different $(P<0.05)$.

$0.25 \mathrm{CF}=0.25 \%$ citrus fiber; $0.50 \mathrm{CF}=0.50 \%$ citrus fiber; $\mathrm{PHO}=$ sodium tripolyphosphate; $\mathrm{SEM}=$ standard error of the mean. 
texture, moistness, turkey flavor, off-flavor, or lightness. Moistness in both citrus fiber treatments was lower $(P<0.05)$ than in $\mathrm{PHO}$, but no storage time effect was observed $(P>0.05)$. In a study of restructured steaks, Chen and Trout (1991) observed that juiciness was higher in steaks with salt and phosphates than in steaks made with various binders. Turkey aroma was less intense $(P<0.05)$ on days 14 and 84 than on days 28 and 56. García et al. (2002) found that the addition of cereal and fruit fibers caused decreased sensory and textural properties in low-fat and dry fermented sausages. Our data indicate that citrus fiber affected moistness but none of the other sensory properties measured.

\section{Conclusions}

The CON, citrus fiber treatments $(0.25 \mathrm{CF}, 0.50 \mathrm{CF})$, and phosphate treatment $(\mathrm{PHO})$ all maintained equivalent quality throughout the 84-d storage period. It must be noted, however, that the phosphate level used in this study $(0.105 \%$ of total product) was generally lower than in many commercial products and that higher phosphate levels would be expected to result in improved quality compared with a no-phosphate control. Although citrus fiber has been demonstrated to provide numerous benefits in various meat applications (Fernández-Ginés et al. 2003; Fernández-López et al., 2004; Powell et al., 2019), at the levels tested in this specific product (high moisture, low fat), it did not affect the product's quality attributes in a measurable way and is therefore unsuitable as a replacer of phosphate or other binder ingredients. Testing at higher usage levels is, therefore, needed in order to ascertain its full potential.

\section{Acknowledgments}

The authors thank Christine A. Fedler, Elaine M. Larson, and the staff of the Iowa State University Meat Laboratory for their technical assistance.

\section{Literature Cited}

Anderson, E. T., and B. W. Berry. 2000. Sensory, shear, and cooking properties of lower-fat beef patties made with inner pea fiber. J. Food Sci. 65:805-810. https://doi.org/10.1111/j. 1365-2621.2000.tb13591.x.

AOAC International. 2016. O cial methods of analysis of AOAC International. 20th ed. AOAC International, Gaithersburg, MD.

Baines, D., and R. Seal, editors. 2012. Natural food additives, ingredients and flavourings. Woodhead Publishing, Cambridge, UK.

Beggs, K. L. H., J. A. Bowers, and D. Brown. 1997. Sensory and physical characteristics of reduced-fat turkey frankfurters with modified corn starch and water. J. Food Sci. 62:1240-1244. https://doi.org/10.1111/j.1365-2621.1997.tb12253.x.

Bourne, M. C. 1978. Texture profile analysis. Food Technol.Chicago 32:62-66,72.

Câmara, A. K. F. I., V. A. S. Vidal, M. Santos, O. D. Bernardelli, E. Sabadini, and M. A. R. Pollonio. 2020. Reducing phosphate in emulsified meat products by adding chia (Salvia hispanica L.) mucilage in powder or gel format: A clean label technological strategy. Meat Sci. 163:108085. https://doi.org/10.1016/j. meatsci.2020.108085.

Chang, H.-C., and J. A. Carpenter. 1997. Optimizing quality of frankfurters containing oat bran and added water. J. Food Sci. 62:194-197. https://doi.org/10.1111/j.1365-2621.1997. tb04398.x.

Chen, C. M., and G. R. Trout. 1991. Sensory, instrumental texture profile and cooking properties of restructured beef steaks made with various binders. J. Food Sci. 56:1457-1460. https://doi.org/10.1111/j.1365-2621.1991.tb08615.x.

Choe, J., J. Lee, K. Jo, C. Jo, M. Song, and S. Jung. 2018. Application of winter mushroom powder as an alternative to phosphates in emulsion-type sausages. Meat Sci. 143:114-118. https://doi.org/10.1016/j.meatsci.2018.04.038.

Choi, Y.-S., J.-H. Choi, D.-J. Han, H.-Y. Kim, M.-A. Lee, J.-Y. Jeong, H.-J. Chung, and C.-J. Kim. 2010. Effects of replacing pork back fat with vegetable oils and rice bran fiber on the quality of reduced-fat frankfurters. Meat Sci. 84:557-563. https://doi.org/10.1016/j.meatsci.2009.10.012.

Claus, J. R., and M. C. Hunt. 1991. Low-fat, high added-water bologna formulated with texture-modifying ingredients. J. Food Sci. 56:643-647. https://doi.org/10.1111/j.1365-2621.1991. tb05347.x.

Desmond, E. M., and D. J. Troy. 2003. Sensory and physical characteristics of pork sausages manufactured with dietary fibers. Irish J. Agr. Food Res. 42:161.

Fernández-Ginés, J. M., J. Fernández-López, E. Sayas-Barberá, E. Sendra, and J. A. Pérez-Alvarez. 2003. Effects of storage conditions on quality characteristics of bologna sausages made with citrus fiber. J. Food Sci. 68:710-714. https://doi.org/ 10.1111/j.1365-2621.2003.tb05737.x.

Fernández-López, J., J. M. Fernández-Ginés, L. Aleson-Carbonell, E. Sendra, E. Sayas-Barberá, and J. A. Pérez-Álvarez, J. A. 2004. Application of functional citrus by-products to meat products. Trends Food Sci. Tech. 15:176-185. https://doi. org/10.1016/j.tifs.2003.08.007.

García, M. L., R. Dominguez, M. D. Galvez, C. Casas, and M. D. Selgas. 2002. Utilization of cereal and fruit fibres in low fat dry fermented sausages. Meat Sci. 60:227-236. https://doi. org/10.1016/s0309-1740(01)00125-5.

Hurtado, S., E. Saguer, M. Toldrà, D. Parés, and C. Carretero. 2012. Porcine plasma as polyphosphate and caseinate replacer in frankfurters. Meat Sci. 90:624-628. https://doi.org/10.1016/ j.meatsci.2011.10.004.

Kim, H.-W., Y. J. Lee, and Y. H. B. Kim. 2015. Efficacy of pectin and insoluble fiber extracted from soy hulls as a functional non-meat ingredient. LWT-Food Sci. Technol. 64:10711077. https://doi.org/10.1016/j.lwt.2015.07.030.

Lee, N., V. Sharma, N. Brown, and A. Mohan. 2015. Functional properties of bicarbonates and lactic acid on chicken breast 
retail display properties and cooked meat quality. Poultry Sci. 94:302-310. https://doi.org/10.3382/ps/peu063.

LeMaster, M. N., S. C. Chauhan, M. P. Wick, D. L. Clark, and E. M England. 2019. Potassium carbonate improves fresh pork quality characteristics. Meat Sci. 156:222-230. https://doi. org/10.1016/j.meatsci.2019.05.019.

Lundberg, B. 2005. Using highly expanded citrus fiber to improve the quality and nutritional properties of foods. Cereal Food World 50:248-252.

Lundberg, B., X. Pan, A. White, H. Chau, and A. Hotchkiss. 2014. Rheology and composition of citrus fiber. J. Food Eng. 125:97-104. https://doi.org/10.1016/j.jfoodeng.2013.10.021.

Mansour, E. H., and A. H. Khalil. 1999. Characteristics of low-fat beefburgers as influenced by various types of wheat fibres. J. Sci. Food Agr. 79:493-498. https://doi.org/10.1002/(SICI) 1097-0010(19990315)79:4<493::AID-JSFA4>3.0.CO;2-5.

Omana, D. A., Z. Pietrasik, and M. Betti. 2012. Use of poultry protein isolate as a food ingredient: Sensory and color characteristics of low-fat turkey bologna. J. Food Sci. 77:S274-S280. https://doi.org/10.1111/j.1750-3841.2012.02772.x.

Pietrasik, Z., and J. A. M. Janz. 2010. Utilization of pea flour, starchrich and fiber-rich fractions in low fat bologna. Food Res. Int. 43:602-608. https://doi.org/10.1016/j.foodres.2009.07.017.

Powell M. J., J. G. Sebranek, K. J. Prusa, and R. Tarté. 2019. Evaluation of citrus fiber as a natural replacer of sodium phosphate in alternatively-cured all-pork Bologna sausage. Meat Sci. 157:107883. https://doi.org/10.1016/j.meatsci.2019.107883.

Ruusunen, M., J. Vainionpää, E. Poulanne, M. Lyly, L. Lähteenmäki, M. Niemistö, and R. Ahvenainen. 2003. Physical and sensory properties of low-salt phosphate-free frankfurters composed with various ingredients. Meat Sci. 63:9-16. https://doi.org/10.1016/S0309-1740(02)00044-X.
Sebranek, J. G., and J. N. Bacus. 2007. Cured meat products without direct addition of nitrate or nitrite: What are the issues? Meat Sci. 77:136-147. https://doi.org/10.1016/j.meatsci.2007.03.025.

Sen, A. R., B. M. Naveena, M. Muthukumar, Y. Babji, and T. R. K. Murthy. 2005. Effect of chilling, polyphosphate and bicarbonate on quality characteristics of broiler breast meat. Brit. Poultry Sci. 46:451-456. https://doi.org/10.1080/00071660500191072.

Song, J., T. Pan, J. Wu, and F. Ren. 2016. The improvement effect and mechanism of citrus fiber on the water-binding ability of low-fat frankfurters. J. Food Sci. Tech. 53:4197-4204. https:// doi.org/10.1007/s13197-016-2407-5.

Steenblock, R. L., J. G. Sebranek, D. G. Olson, and J. A. Love. 2001. The effects of oat fiber on the properties of light bologna and fat-free frankfurters. J. Food Sci 63:1409-1415. https:// doi.org/10.1111/j.1365-2621.2001.tb15223.x.

Tarladgis, B. G., B. M. Watts, M. T. Younathan, and L. Dugan, Jr. 1960. A distillation method for the quantitative determination of malonaldehyde in rancid foods. J. Am. Oil Chem. Soc. 37:44-48. https://doi.org/10.1007/BF02630824.

Tomaschunas, M., R. Zörb, J. Fischer, E. Köhn, J. Hinrichs, and M. Busch-Stockfisch. 2013. Changes in sensory properties and consumer acceptance of reduced fat pork Lyon-style and liver sausages containing inulin and citrus fiber as fat replacers. Meat Sci. 95:629-640. https://doi.org/10.1016/j.meatsci.2013.06.002.

Trowell, H., D. Burkitt, and K. Heaton, editors. 1985. Dietary fibre, fibre-depleted foods and disease. Academic Press, London.

Xiong, Y. L. 2000. Meat processing. In: S. Nakai and H. W. Modler, editors. Food proteins: Processing applications. Wiley-VCH, New York. p. 89-145.

Zipser, M. W., and B. M. Watts. 1962. A modified 2-thiobarbituric acid (TBA) method for the determination of malonaldehyde in cured meats. Food Technol.-Chicago. 16:102-104. 